\title{
Acute liver failure in a term neonate after repeated paracetamol administration
}

\author{
Falência hepática aguda em neonato de termo após ingestão de doses repetidas de paracetamol \\ Falencia hepática aguda en neonato a término después de la ingestión de dosis repetidas de paracetamol
}

Fábio Bucaretchi', Carla Borrasca Fernandes², Maíra Migliari Branco ${ }^{2}$, Eduardo Mello De Capitani ${ }^{3}$, Stephen Hyslop ${ }^{4}$,

Jamil Pedro S. Caldas ${ }^{5}$, Carolina Araújo Moreno ${ }^{6}$, Gilda Porta ${ }^{7}$

\section{ABSTRACT}

Objective: Severe hepatotoxicity caused by paracetamol is rare in neonates. We report a case of paracetamol-induced acute liver failure in a term neonate.

Case description: A 26-day-old boy was admitted with intestinal bleeding, shock signs, slight liver enlargement, coagulopathy, metabolic acidosis $(\mathrm{pH}=7.21$; bicarbonate: $7.1 \mathrm{mEq} / \mathrm{L})$, hypoglycemia $(18 \mathrm{mg} / \mathrm{dL})$, increased serum aminotransferase activity (AST $=4,039 \mathrm{IU} / \mathrm{L} ; \mathrm{ALT}=1,087 \mathrm{IU} / \mathrm{L})$ and hyperbilirubinemia (total: $9.57 \mathrm{mg} / \mathrm{dL}$; direct: $6.18 \mathrm{mg} / \mathrm{dL}$ ) after receiving oral paracetamol ( $10 \mathrm{mg} / \mathrm{kg} /$ dose every 4 hours) for three consecutive days (total dose around $180 \mathrm{mg} / \mathrm{kg}$; serum concentration 36-48 hours after the last dose of $77 \mu \mathrm{g} /$ $\mathrm{mL})$. Apart from supportive measures, the patient was successfully treated with intravenous $\mathrm{N}$-acetylcysteine infusion during 11 consecutive days, and was discharged on day 34 . The follow-up revealed full recovery of clinical and of laboratory findings of hepatic function.

Comments: The paracetamol pharmacokinetics and pharmacodynamics in neonates and infants differ substantially from those in older children and adults. Despite the reduced rates of metabolism by the P-450 CYP2E1 enzyme system and the increased ability to synthesize glutathione — which provides greater resistance after overdoses - , it is possible to produce hepatotoxic metabolites ( $\mathrm{N}$-acetyl-p-benzoquinone) that cause hepatocellular damage, if glutathione sources are depleted. Paracetamol clearance is reduced and the half-life of elimination is prolonged. Therefore, a particular dosing regimen should be followed due to the toxicity risk of cumulative doses. This report highlights the risk for severe hepatotoxicity in neonates after paracetamol multiple doses for more than two to three days.

Key-words: acetaminophen; liver failure; infant, newborn; $\mathrm{N}$-acetylcysteine.

\section{RESUMO}

Objetivo: A hepatoxicidade grave induzida pelo paracetamol é muito rara em neonatos. Relata-se o caso de um neonato de termo que desenvolveu falência hepática aguda após o uso de paracetamol.

Descrição do caso: Menino, 26 dias, admitido com sangramento intestinal, sinais de choque, discreta hepatomegalia, coagulopatia, acidose metabólica $(\mathrm{pH}=7,21$; bicarbonato: $7,1 \mathrm{mEq} / \mathrm{L})$, hipoglicemia $(18 \mathrm{mg} / \mathrm{dL})$, aumento das aminotransferases séricas $(\mathrm{AST}=4.039 \mathrm{UI} / \mathrm{L}$;
Instituição: Faculdade de Ciências Médicas da Universidade Estadual de Campinas (Unicamp), Campinas, SP, Brasil

'Departamento de Pediatria da Faculdade de Ciências Médicas da Unicamp, Campinas, SP, Brasil

${ }^{2}$ Centro de Controle de Intoxicações da Faculdade de Ciências Médicas da Unicamp, Campinas, SP, Brasil

${ }^{3}$ Departamento de Clínica Médica da Faculdade de Ciências Médicas da Unicamp, Campinas, SP, Brasil

${ }^{4}$ Departamento de Farmacologia da Faculdade de Ciências Médicas da Unicamp, Campinas, SP, Brasil

${ }^{5}$ Unidade de Terapia Intensiva Neonatal do Hospital da Mulher Professor Doutor José Aristodemo Pinotti da Unicamp, Campinas, SP, Brasil

${ }^{6}$ Programa de Genética Perinatal do Hospital da Mulher Professor Doutor José Aristodemo Pinotti da Unicamp, Campinas, SP, Brasil

${ }^{7}$ Departamento de Pediatria da Faculdade de Medicina da Universidade de São Paulo (USP), São Paulo, SP, Brasil
Endereço para correspondência:

Fábio Bucaretchi

Rua Tessália Vieira de Camargo, 126 - Cidade Universitária Zeferino Vaz CEP 13083-887 - Campinas/SP

E-mail: bucaret@fcm.unicamp.br

Conflito de interesse: nada a declarar

Recebido em: 1/4/2013

Aprovado em: 19/5/2013 
ALT $=1.087 \mathrm{UI} / \mathrm{L}$ ) e hiperbilirrubinemia (total: $9,57 \mathrm{mg} / \mathrm{dL}$; direta: $6,18 \mathrm{mg} / \mathrm{dL}$ ), após uso de paracetamol via oral $(10 \mathrm{mg} / \mathrm{kg} /$ dose a cada quatro horas) por três dias consecutivos (dose total ao redor de $180 \mathrm{mg} / \mathrm{kg}$; nível sérico de 36-48 horas após a última dose de $77 \mu \mathrm{g} / \mathrm{mL}$ ). Além das medidas de suporte, o paciente foi tratado com $\mathrm{N}$-acetilcisteína (infusão intravenosa contínua por 11 dias consecutivos), recebendo alta após 34 dias de internação. O seguimento mostrou recuperação clínica e dos parâmetros laboratoriais da função hepática.

Comentários: A farmacocinética e a farmacodinâmica do paracetamol em neonatos e lactentes jovens (menores de um ano) diferem substancialmente de crianças maiores e adultos. Apesar de as taxas de metabolismo do sistema enzimático P-450 CYP2E1 estarem diminuídas e a capacidade de gerar glutationa, aumentadas — conferindo maior proteção após superdosagens —, existe a possibilidade de produção de metabólitos hepatotóxicos ( $\mathrm{N}$-acetil-p-benzoquinoneimina) que determinam lise celular, caso se esgotem as reservas de glutationa. A depuração é diminuída e a meia-vida de eliminação é prolongada, recomendando-se posologia distinta pelo risco de toxicidade de doses cumulativas. $\mathrm{O}$ presente relato destaca o risco de hepatotoxicidade grave em neonatos após o uso contínuo de paracetamol por mais de dois a três dias.

Palavras-chave: acetaminofen; falência hepática; recém-nascido; $\mathrm{N}$-acetilcisteína.

\section{RESUMEN}

Objetivo: La hepatotoxicidad grave inducida por el paracetamol es muy rara en neonatos. Se relata el caso de un neonato a término que desarrolló falencia hepática aguda después del uso de paracetamol.

Descripción del caso: Niño, 26 días, admitido con sangrado intestinal, señales de choque, discreta hepatomegalia, coagulopatía, acidosis metabólica ( $\mathrm{pH}=7,21$; bicarbonato: $7,1 \mathrm{mEq} / \mathrm{L}$ ), hipoglucemia $(18 \mathrm{mg} / \mathrm{dL})$, aumento de las aminotransferasas séricas $(\mathrm{AST}=4.039 \mathrm{UI} / \mathrm{L} ; \mathrm{ALT}=1.087 \mathrm{UI} / \mathrm{L})$ e hiperbilirrubinemia (total: $9,75 \mathrm{mg} / \mathrm{dL}$; directa: $6,18 \mathrm{mg} / \mathrm{dL}$ ), después del uso de paracetamol por vía oral $(10 \mathrm{mg} / \mathrm{kg} / \mathrm{dosis}$ a cada cuatro horas) durante tres días consecutivos (dosis alrededor de $180 \mathrm{mg} / \mathrm{kg}$; nivel sérico de 36-48 horas después de la última dosis de $77 \mu \mathrm{g} / \mathrm{mL}$ ). Además de las medidas de soporte, el paciente fue tratado con $\mathrm{N}$-acetilcisteína (infusión intravenosa continua por 11 días consecutivos), recibiendo alta después de 34 días de internación. El seguimiento mostró recuperación clínica y de los parámetros laboratoriales de la función hepática.
Comentarios: La farmacocinética y la farmacodinámica del paracetamol en neonatos y lactantes jóvenes (menores de un año) difieren substancialmente de niños más grandes y adultos. A pesar de que las tasas de metabolismo del sistema enzimático P-450 CYP2E1 están reducidas y la capacidad de generar glutatión, aumentada — confiriendo más protección después de superdosis —, existe la posibilidad de producción de metabólitos hepatotóxicos ( $\mathrm{N}$-acetil-pbenzoquinoneimina) que determinan lisis celular, caso se agoten las reservas de glutatión. La depuración es reducida y la media vida de la eliminación, alargada, recomendándose posología distinta por el riesgo de toxicidad de dosis cumulativas. El presente relato subraya el riesgo de hepatotoxicidad grave en neonatos después del uso continuo de paracetamol por más de dos a tres días.

Palabras clave: acetaminofeno; falencia hepática; recién nacido; $\mathrm{N}$-acetilcisteína.

\section{Introduction}

Paracetamol (N-acetyl-p-aminophenol) is a widely used analgesic and antipyretic in children; however, toxic exposures are rare in neonates. Toxic exposures may occur via the placenta, resulting from intentional ingestion of overdoses of paracetamol by mothers in the 24 hours preceding delivery ${ }^{(1-3)}$, due to isolated oral ${ }^{(4)}$ or intravenous dosing errors (propacetamol, pro-drug of paracetamol, not available in Brazil $)^{(5,6)}$, in general, on the order of 10 times the therapeutic dose, or due to repeated doses orally ${ }^{(7)}$.

The severe hepatotoxicity induced by paracetamol, with or without acute liver failure, is almost not described in the neonatal period. In a review of 97 cases of acute liver failure in patients aged $<17$ years, in two regional reference units of liver transplantation in the United Kingdom (1991-2000), there were no cases of liver failure by medications in the neonatal group ( $\mathrm{n}=17$; metabolic diseases - ten cases; infectious diseases seven cases). However, paracetamol was the main product associated with liver failure ( 14 out of 19 cases), particularly in the age group older than 5 years $(\mathrm{n}=11)$, resulting in seven deaths ${ }^{(8)}$. Another study analyzed a series of 51 children and adolescents who developed hepatotoxicity induced by paracetamol ( 45 by isolated overdose and six by repeated and cumulative doses), all with serum levels of aspartate aminotransferase (AST) or alanine aminotransferase (ALT) $>1,000 \mathrm{UI} / \mathrm{L}$, and 11 progressed to liver failure (encephalopathy and/or coagulopathy). Among these, six were submitted to liver transplantation — two survived — and 
the other five died waiting for transplantation. The youngest patient in this series was 10 months old ${ }^{(9)}$.

In an extensive review conducted by Arana et al, regarding the period from 1978 to 2001, no cases of acetaminophen poisoning by direct administration in neonates were reported $^{(10)}$. In 2007, Walls et al described the first case of liver failure in a term neonate with 4 days of life after the use of paracetamol orally for 3 consecutive days (weight $3.1 \mathrm{~kg}$; $26 \mathrm{mg} / \mathrm{kg} / \mathrm{dose}$ every 4 hours on the 1 st day; $13 \mathrm{mg} / \mathrm{kg} / \mathrm{dose}$ every 4 hours on the 2 nd and 3 rd days; total cumulative dose of approximately $312 \mathrm{mg} / \mathrm{kg}$ ), prescribed as an analgesic postoperatively after a circumcision performed on the 1 st day of life, detecting serum level of acetaminophen of $109.8 \mu \mathrm{g} / \mathrm{mL}, 16$ hours after the last dose. The patient showed complete recovery after continuous intravenous infusion of $\mathrm{N}$-acetylcysteine for 36 hours, evolving without sequelae ${ }^{(7)}$.

The present study described a new case of liver failure in term neonate after repeated doses of paracetamol, treated successfully with $\mathrm{N}$-acetylcysteine.

\section{Case description}

Male patient, 26 days old, weighing 3,125g, son of nonconsanguineous parents, sent by the local emergency unit where he remained hospitalized for 24 hours with a history of irritability, refusal to eat for 4 days, frequent vomiting for 1 day, abdominal distension and slight respiratory distress. The delivery (iterative cesarean section) was uneventful, and the neonate presented birth weight of $3,160 \mathrm{~g}, 48 \mathrm{~cm}$, Apgar score 8 and 10 (1st and 5th minutes), and Capurro score of 39 weeks and 3 days. The mother, 38 years old, had 10 previous pregnancies (two cesareans), was confined in a penitentiary since the 5 th month of pregnancy and had a history of losing custody of nine children due to negligence associated with addiction (crack).
Before admission, the child was exclusively breastfed, on maternal care in a rooming in prison. The mother reported having administered paracetamol orally $(10 \mathrm{mg} / \mathrm{kg} /$ dose every 4 hours for 3 consecutive days — total dose of approximately $180 \mathrm{mg} / \mathrm{kg}$, according to previous prescription to another son), claiming that, a week ago the child was weepy and "feverish". She also reported the concomitant use of paracetamol for 5 days for relief of toothache (doses and frequency of use were not obtained).

At admission (D1), the child was afebrile with signs of shock (heart rate $-\mathrm{HR}=183 \mathrm{bpm}$, slow capillary refill, weak pulse, inaudible blood pressure and mottled skin), jaundice, hepatomegaly and massive upper gastrointestinal bleeding. The main laboratory findings obtained in the first 24 hours of admission included coagulopathy (incoagulable international normalized ratio - INR, activated partial thromboplastin time - APTT, and thrombin time - TT), metabolic acidosis ( $\mathrm{pH} 7,21$; bicarbonate $7,1 \mathrm{mEq} / \mathrm{L}$; lactate $4,3 \mathrm{mmol} / \mathrm{L}$ ), hypoglycemia $(18 \mathrm{mg} / \mathrm{dL})$, AST - 4,039UI/L, ALT - 1,087UI/L and hyperbilirubinemia (total bilirubin $-9.57 \mathrm{mg} / \mathrm{dL}$; direct $6.18 \mathrm{mg} / \mathrm{dL}$ ). During hospitalization, there was a progressive fall in hemoglobin levels: D1 - 10.6g/dL; 3rd day of hospitalization (D3) $-8.0 \mathrm{~g} / \mathrm{dL}$. Serum concentration of paracetamol (approximately 36-48 hours after the last dose) was of $77 \mu \mathrm{g} / \mathrm{mL}$ (therapeutic range of $10-20 \mu \mathrm{g} / \mathrm{mL}$, spectrophotometric method). Considering the possibility of consumption by the mother and passage through breast milk, a screening of recreational drugs (cocaine, cannabinoids, methamphetamine and amphetamine) was performed by an immunochromatographic test in the patient's urine, with negative results. Blood cultures collected on admission were also negative.

Supportive measures included: volume replacement, correction of hypoglycaemia, serial transfusions of fresh frozen plasma, dobutamine, mechanical ventilation, empirical antibiotic therapy (ampicillin and amikacin in D1-D3, while waiting for

Table 1 - Main laboratory findings during hospitalization

\begin{tabular}{lccccccccccc}
\hline Day $(\mathbf{D})$ & D1 & D2 & D3 & D4 & D5 & D7 & D8 & D9 & D11 & D12 & D30 \\
\hline ALT $(R V<45 U I / L)$ & 1,087 & 633 & 339 & 240 & 168 & 107 & 87 & 82 & 79 & 115 & 67 \\
AST $(R V<60 U I / L)$ & 4,039 & 1,169 & 319 & 101 & 47 & 34 & 37 & 52 & 94 & 124 & 62 \\
Total Bilirubin $(\mathrm{RV}<1.0 \mathrm{mg} / \mathrm{dL})$ & 9.6 & $\mathrm{NR}$ & 19.9 & 26.0 & 23.3 & $\mathrm{NR}$ & 14.0 & 11.7 & 9.4 & $\mathrm{NR}$ & 2.6 \\
Direct Bilirubin $(\mathrm{RV}<0.3 \mathrm{mg} / \mathrm{dL})$ & 6.2 & $\mathrm{NR}$ & 18.5 & 18.4 & 19.8 & $\mathrm{NR}$ & 8.1 & 6.6 & 7.1 & 4.7 & 2.1 \\
Paracetamol $(\mathrm{TR}: 10-20 \mu \mathrm{g} / \mathrm{mL})$ & 77 & $\mathrm{NR}$ & $\mathrm{NR}$ & $\mathrm{NR}$ & 11 & $\mathrm{NR}$ & $\mathrm{NR}$ & $\mathrm{NR}$ & $\mathrm{NR}$ & $\mathrm{NR}$ & $\mathrm{NR}$ \\
INR $(\mathrm{RV}<1.2)$ & $\mathrm{INC}$ & 7.9 & 2.6 & 2.8 & 3.3 & 2.8 & $\mathrm{NR}$ & 1.8 & 1.4 & 1.27 & 1.4 \\
Ammonia $(\mathrm{RV}=79-150 \mu \mathrm{g} / \mathrm{dL})$ & $\mathrm{NR}$ & 308 & 367 & 410 & 234 & 289 & $\mathrm{NR}$ & 241 & $\mathrm{NR}$ & 53 & $\mathrm{NR}$ \\
Albumin $(\mathrm{RV}=2.5-5.5 \mathrm{~g} / \mathrm{dL})$ & $\mathrm{NR}$ & 2.4 & 2.0 & 2.2 & 2.3 & 2.2 & 2.1 & 2.2 & $\mathrm{NR}$ & $\mathrm{NR}$ & $\mathrm{NR}$ \\
\hline
\end{tabular}

ALT: alanine aminotransferase; AST: aspartate aminotransferase; RV: reference values; TR: therapeutic range; INR: international normalized ratio; NP: examination not performed; INC: incoagulable 
completion of infectious screening), and transfusion of red blood cells (D3). After laboratory confirmation of toxic exposure to paracetamol, the protocol of continuous intravenous infusion of $\mathrm{N}$-acetylcysteine in 21 hours was introduced $(150 \mathrm{mg} / \mathrm{kg}$ in 60 minutes; $50 \mathrm{mg} / \mathrm{kg}$ in 4 hours; $100 \mathrm{mg} / \mathrm{kg}$ in 16 hours $)^{(11)}$, maintained at $6.25 \mathrm{mg} / \mathrm{kg} /$ hour until D11. Given the severity of the case and the possibility of progression to liver transplantation, the patient was transferred to the regional referral unit at D3, where he stayed for 19 days. During evolution, there was a progressive decrease of aminotransferase concentrations and improvement of coagulation; infusion of $\mathrm{N}$-acetylcysteine was suspended on D11. The patient developed hospital infection by oxacillin-resistant Staphylococcus aureus (D20), treated with vancomycin. In Table 1 are summarized the main laboratory results achieved during the 34 days of hospitalization.

In the screening of metabolic diseases that may present with liver failure in the neonatal period, the analysis of the acylcarnitine profile in D2 showed reduced free serum carnitine $(5.03 \mathrm{~mol} / \mathrm{L}$; reference values: $17.8-51.8 \mathrm{~mol} / \mathrm{L})$, with values within the normal range both in the material obtained in newborn screening tests and in dosages performed after resolution of the clinical condition (D30 and D180). Research for galactosemia, tyrosinemia, and organic acidemia was negative. Prenatal serological testing for HIV, toxoplasmosis, syphilis, and hepatitis B and C were also negative. The outpatient follow-up undertaken for one year showed complete clinical and laboratory recovery and adequate neuropsychomotor development.

\section{Discussion}

In general, the time of peak absorption following ingestion of paracetamol is rapid (30-45 minutes), with analgesic and antipyretic action achieved with serum concentrations of 10 and $4-18 \mu \mathrm{g} / \mathrm{mL}$, respectively, including in children. About $90 \%$ of paracetamol is conjugated in the liver (glucuronidation - 40-67\%; sulfation - 20-46\%), forming inactive metabolites excreted in the urine. Approximately $5-15 \%$ of the drug is oxidized in the CYP2E1 and, to a lesser extent in the CYP2A6, CYP1A2, and CYP3A4, resulting in the formation of toxic metabolite $\mathrm{N}$-acetyl-p-benzoquinone imine (NAPQI), which readily combines with glutathione, turning into nontoxic cysteine/mercaptate conjugates eliminated in urine. The hepatotoxic action of paracetamol is associated primarily to the activity of the CYP2E1 enzyme system and the production of NAPQI ${ }^{(12)}$. In overdoses with clinical repercussion, by isolated overdoses or after supratherapeutic doses, the maximum rates of glucuronidation and sulfation are reached and the availability of glutathione is insufficient to metabolize NAPQI. Then, the free NAPQI binds covalently to hepatic proteins of the cysteine group, triggering hepatotoxicity and cell death ${ }^{(12,13)}$. Acetaminophen-protein products, such as 3-(cysteine-S-yl)-paracetamol-adduct are released into the blood after hepatocyte lysis. They are measured by high performance liquid chromatography with electrochemical detection and may be used as specific biomarkers of hepatotoxicity, even several days after the exposure ${ }^{(13)}$. A study in adults who developed liver failure induced by paracetamol overdoses showed a positive correlation between the serum concentration of acetaminophenprotein adducts and severity of hepatotoxicity, which can be detected up to 12 days after ingestion ${ }^{(13)}$.

In contrast, the pharmacokinetics and pharmacodynamics of paracetamol in neonates and young infants (under 1 year) differ substantially from older children and adults. The combination with glucuronides is immature, while sulfation is well developed, consisting in the main metabolic pathway ${ }^{(1,2,10,14)}$. The clearance of paracetamol in term neonates is decreased and the half-life is prolonged compared to that of adults (approximately 3.5 versus 1.9-2.2 hours), so a distinct dosage is recommended (20 mg $/ \mathrm{kg} / \mathrm{dose}$, every 8 hours, no longer than 48 hours of use), due to the risk of toxicity of cumulative doses ${ }^{(10,14)}$. In addition, the elimination half-life of paracetamol may be extended further after multiple doses, in poisoned patients and in those who develop liver failure ${ }^{(2,10,12,14)}$. Although the rates of metabolism of CYP2E1 were decreased and the ability to generate glutathione, increased, providing greater protection after isolated overdoses, neonates may also produce toxic metabolites (NAPQI) ${ }^{(1,10,14)}$, triggering up hepatotoxicity and cell lysis if glutathione reserves are depleted ${ }^{(10,12,14)}$. It should be noted that paracetamol-protein products could also be used as specific biomarkers of hepatotoxicity in children, especially to assist the diagnosis of acute liver failure of unknown etiology ${ }^{(15)}$.

Even considering the background of the mother, which could raise doubts about the actual dose, the continuous use of medication for 3 days, the possible additional doses transferred through breast milk, and the high serum paracetamol levels detected established a causal relationship between prolonged use drug and liver failure. Reinforcing these findings, Penna and Buchanan described in their review the cases of two young infants, 6 to 7 weeks of life, who also developed severe hepatotoxicity after ingesting repeated doses of paracetamol (approximately $100 \mathrm{mg} / \mathrm{kg} /$ day $/ 2$ days and $60 \mathrm{mg} / \mathrm{kg} /$ day $/ 6$ days, respectively) ${ }^{(16)}$.

$\mathrm{N}$-acetylcysteine is the antidote of choice in the treatment of acetaminophen poisoning, being a precursor of reduced 
glutathione, which, when given early, can prevent liver damage induced by paracetamol, restoring glutathione levels ${ }^{(11,12,17)}$. When the moment of exposure is known, the administration of $\mathrm{N}$-acetylcysteine is formally indicated after ingestion of isolated overdoses of paracetamol, when the serum levels, preferably obtained between 4 and 8 hours of ingestion are above the possible risk line on the Rumack-Matthew nomogram, even without clinical or laboratory evidence of liver injury ${ }^{(11,12)}$. When the time of exposure is unknown or it is not possible to get the serum concentration levels within 8 hours of exposure, but the estimated dose is above $200 \mathrm{mg} / \mathrm{kg}$ in the last 24 hours (or $\geq 10 \mathrm{~g}$ in adolescents and adults), the use of $\mathrm{N}$-acetylcysteine is also indicated, and the decision about the suspension of treatment is based on clinical and laboratory progress ${ }^{(11,12,17,18)}$.

Other more complex situations involve the indication of $\mathrm{N}$-acetylcysteine after prolonged or supratherapeutic use of paracetamol, when assessing the risk of hepatotoxicity by the Rumack-Matthew nomogram is not possible ${ }^{(11,12,17-19)}$. In general, it is recommended the use of $\mathrm{N}$-acetylcysteine when the serum concentration of paracetamol is above $10 \mu \mathrm{g} / \mathrm{mL}$ or $\mathrm{AST}>50 \mathrm{UI} / \mathrm{L}^{(11,12,19)}$. In patients with liver failure, as described, $\mathrm{N}$-acetylcysteine also possibly acts as an antioxidant, improving hemodynamics, oxygen consumption, and cerebral edema ${ }^{(17)}$. Patients with paracetamol-induced

\section{References}

1. Lederman S, Fysh WJ, Tredger M, Gamsu HR. Neonatal paracetamol poisoning: treatment by exchange transfusion. Arch Dis Child 1983;58:631-3.

2. Roberts I, Robinson MJ, Mughal MZ, Ratcliffe G, Prescott LF. Paracetamol metabolites in the neonate following maternal overdose. Br J Clin Pharmacol 1984;18:201-6.

3. AW MM, Dhawan A, Baker AJ, Mieli-Vergani G. Neonatal paracetamol poisoning. Arch Dis Child Fetal Neonatal Ed 1999;81:F78.

4. Isbister GK, Bucens IK, Whyte IM. Paracetamol overdose in a preterm neonate. Arch Dis Child Fetal Neonatal Ed 2001;85:F70-2.

5. De la Pintiére A, Beuchée A, Bétrémieux PE. Intravenous propacetamol overdose in a term newborn. Arch Dis Child Fetal Neonatal Ed 2003;88:F351-2.

6. Nevin DG, Shung J. Intravenous paracetamol overdose in a preterm infant during anesthesia. Paediatr Anaesth 2010;20:105-7.

7. Walls L, Baker CF, Sarkar S. Acetaminophen-induced hepatic failure with encephalopathy in a newborn. J Perinatol 2007;27:133-5.

8. Lee WS, McKiernan P, Kelly DA. Etiology, outcome and prognostic indicators of childhood fulminant hepatic failure in the United Kingdom. J Pediatr Gastroenterol Nutr 2005;40:575-81.

9. Mahadevan SB, McKiernan PJ, Davies P, Kelly DA. Paracetamol induced hepatotoxicity. Arch Dis Child 2006;91:598-603.

10. Arana A, Morton NS, Hansen TG. Treatment with paracetamol in infants. Acta Anaesthesiol Scand 2001;45:20-9.

11. Howland MA, Hendrickson RG. Antidotes in depth. N-acetylcysteine. In: Nelson LS, Lewin NA, Howland MA, Hoffman RS, Goldfrank LR, Flomenbaum NE, editors. Goldfrank's toxicologic emergencies. $9^{\text {th }}$ ed. New York: McGraw-Hill; 2011. p. $500-7$ liver failure, either by isolated overdoses or by supratherapeutic doses, should be given intravenous $\mathrm{N}$-acetylcysteine until the encephalopathy resolves itself or until they present significant improvements in the results of ALT, INR, and creatinine or until liver transplantation ${ }^{(11,17)}$. In the present case, continuous intravenous infusion of $\mathrm{N}$-acetylcysteine proved to be effective, safe, and without adverse effects, even in prolonged use.

Although studies in experimental models suggest that carnitine deficiency, as a cause or consequence, may be associated with hepatotoxicity triggered by acetaminophen ${ }^{(20)}$, it would be speculative to infer this association only with the data available in the present report (a single measurement during the course of liver failure). Clinical studies are needed to define and characterize the association more accurately. However, it can be inferred that the laboratory screening, the evolution, and the outpatient follow-up practically exclude the possibility of genetic diseases associated with changes in the carnitine transport and the carnitine cycle, which can evolve with liver failure ${ }^{(21)}$.

It is possible to conclude that the continued use of acetaminophen can cause severe hepatotoxicity in neonates. The specific dosage for term and preterm neonates should be followed, avoiding the continuous use for more than 2 to 3 days ${ }^{(10,14)}$.

12. Hendrickson RG. Acetaminophen. In: Nelson LS, Lewin NA, Howland MA, Hoffman RS, Goldfrank LR, Flomenbaum NE, editors. Goldfrank's toxicologic emergencies. $9^{\text {th }}$ ed. New York: McGraw-Hill; 2011. p. 483-99.

13. James LP, Letzig L, Simpson PM, Capparelli E, Roberts DW, Hinson JA et al. Pharmacokinetics of acetaminophen-protein adducts in adults with acetaminophen overdose and acute liver failure. Drug Metab Dispos 2009;37:1779-84.

14. Anderson BJ, van Lingen RA, Hansen TG, Lin YC, Holford NH. Acetaminophen developmental pharmacokinetics in premature neonates and infants: a pooled population analysis. Anesthesiology 2002;96:1336-45.

15. James LP, Alonso EM, Hynan LS, Hinson JA, Davern TJ, Lee WM et al. Detection of acetaminophen protein adducts in children with acute liver failure of indeterminate cause. Pediatrics 2006;118:e676-81.

16. Penna A, Buchanan N. Paracetamol poisoning in children and hepatotoxicity. Br J Clin Pharmacol 1991;32:143-9.

17. Heard KJ. Acetylcysteine for acetaminophen poisoning. N Engl J Med 2008;359:285-92.

18. Dart RC, Erdman AR, Olson KR, Christianson G, Manoguerra AS, Chyka PA et al. Acetaminophen poisoning: an evidence-based consensus guideline for out-of-hospital management. Clin Toxicol (Phila) 2006;44:1-18.

19. Daly FF, O'Malley GF, Heard K, Bogdan GM, Dart RC. Prospective evaluation of repeated supratherapeutic acetaminophen (paracetamol) ingestion. Ann Emerg Med 2004;44:393-8.

20. Arafa HM. Carnitine deficiency: a possible risk factor in paracetamol hepatotoxicity. Arch Toxicol 2009;83:139-50.

21. Longo N, Amat di San Filippo C, Pasquali M. Disorders of carnitine transport and the carnitine cycle. Am J Med Genet C Semin Med Genet 2006; 142C:77-85 